Original Contribution

\title{
SENSITIVITY OF MCCOY-PLOVDIV CELLS TO G-418 ANTIBIOTIC
}

\author{
V. Alexandrov ${ }^{1}$, Y. Feodorova ${ }^{1}$, M. Draganov ${ }^{1}$, V. Sarafian ${ }^{1}$, S. Naimov ${ }^{2} *$ \\ ${ }^{1}$ Department of Medical Biology, Medical University-Plovdiv, Plovdiv, Bulgaria \\ ${ }^{2}$ Department of Plant Physiology and Molecular Biology, University of Plovdiv, Plovdiv, Bulgaria
}

\begin{abstract}
McCoy-Plovdiv cells represent a serum-free in vitro system, which is suitable not only for diagnostic purposes but also for studies on the biological activity of different substances. In addition, it can be used for developing an expression system for production and purification of various proteins. Isolation of successfully transfected cells is an important step in this process and different selection systems can be employed for this purpose. In order to assess the potential of the antibiotic G-418 as a selective agent for transfection procedures of McCoy-Plovdiv cells, we determined its cytotoxic effect on untransfected cells. Two commercially available versions of the antibiotic were tested: products of Sigma-Aldrich and Duchefa Biochemie. Cells were treated with a wide range of G-418 concentrations and cell vitality was measured with the WST-1 reagent after 48 and 96 hours of treatment. Our results showed that concentrations in the range $0.5-0.6 \mathrm{mg} / \mathrm{ml}$ of G-418 from Sigma-Aldrich efficiently kill untransfected McCoy-Plovdiv cells whereas G-418 from Duchefa Biochemie should be applied at higher concentrations: $0.9-1 \mathrm{mg} / \mathrm{ml}$. Furthermore, medium replacement during treatment led to higher effective antibiotic concentrations and thus to increased cell death rate, exclusively in cultures treated with high G-418 concentrations.
\end{abstract}

Key words: McCoy-Plovdiv cells, cytotoxicity, G-418

\section{INTRODUCTION}

The serum-free cellular in vitro system McCoy-Plovdiv is based on McCoy cells (1) and can be utilized in a wide variety of biomedical studies (2). Serum-free cells are especially suitable for testing the biological activity of different chemicals (3), biological substances (4) and dental monomers (5). Additionally, McCoy-Plovdiv cells represent an ideal system for the diagnosis of chlamydia (6), antinuclear $(7,8)$ and antimitochondrial antibodies (9). As a serum- and protein-free cultural system (10) the cell line McCoyPlovdiv is appropriate for developing an expression system allowing the synthesis and extraction of proteins with biological significance. In transfection experiments enrichment for successfully transfected cells is of crucial significance. To this end, several different selection systems have been developed. Most of them are based on additionally acquired antibiotic or drug resistance. Resistance to the G-418 antibiotic,

\footnotetext{
* Correspondence to: Samir I. Naimov at the Department of Plant Physiology and Molecular Biology, University of Plovdiv, 24 Tsar Assen Street, Plovdiv 4000, Bulgaria; e-mail: samir.naimov@gmail.com; phone number: +359 878265517
}

for example, is achieved by expression of the neomycin phosphotransferase gene, whereas methotrexate resistance is attained by expression of the gene encoding dihydropholate reductase. Other systems rely on depletion of particular supplements from the medium, for instance glutamine, when the glutamine synthetase gene is used as a marker (11). Because of its selective potency for both bacterial (Kanamycin) and mamallian (G-418) cells the neomycin phosphotransferase gene is one of the most widely used selective markers. The enzyme helps cells overcome the inhibiting effects of the aminoglycoside antibiotic G-418 on protein synthesis. It has been reported that mammalian cells have different sensitivity for G-418 (12). Here, we have studied the effect of this antibiotic on McCoy-Plovdiv cells in order to determine the concentrations, which are suitable for transfection experiments.

\section{MATERIALS AND METHODS McCoy-Plovdiv cell culture}

Cells were cultured in medium DMEM/Ham's F-12 1:1 with $15 \mathrm{mM}$ HEPES, 100 units/ml penicillin and $100 \mu \mathrm{g} / \mathrm{ml}$ streptomycin. The procedures for cell culturing and storage were performed as described earlier (10). 


\section{Chemicals and reagents}

For the purpose of this study antibiotic G-418 (disulfate salt) delivered by two commercial suppliers was used: 1) provided by SigmaAldrich (St. Louis, MO, USA, cat \# A1720) referred to as G-418S and 2) supplied by Duchefa Bohemia (Harleem, Netherlands, cat \# G0175.0005) - referred to as G-418D. Cell proliferation was assessed using the reagent WST-1 (Roche Diagnostics, Rotkreuz, Switzerland, cat \# 05015944001).

\section{Cell vitality and cytotoxicity}

McCoy-Plovdiv cells in the exponential growth phase were trypsinized to a single-cell state. $200 \mu \mathrm{l}$ of the cell suspension with a density of $1 \times 10^{5}$ cells $/ \mathrm{ml}$ were seeded in $96-$ well plates. After 24 hours the cells were treated with the studied compounds. Cells were treated with the antibiotics G-418S and G418D in the following concentrations: $0.2,0.4$, $0.6,0.8,1.0,1.2,1.4,1.6,1.8,2.0 \mathrm{mg} / \mathrm{ml}$. Treatment was performed for 48 and 96 hours with or without medium replacement. Cell vitality was determined using WST-1 (Roche Diagnostics). Cells were incubated with WST-
ALEXANDROV V., et al.

1 for 4 hours at $37{ }^{\circ} \mathrm{C}$. The absorbance of the resulting coloured product was measured at $450 / 620 \mathrm{~nm}$ using the ELISA reader Sunrise (Tecan, Switzerland). The state of the cells was analyzed at each stage by light microscopy for changes in cell morphology, state of the cellular monolayer and cell death. Microscopic observations were performed on the inverted microscope Nikon Eclipse TS100 (Nikon, Germany).

\section{RESULTS AND DISCUSSION \\ Sensitivity of McCoy-Plovdiv cells to G- 418S and G-418D}

We treated McCoy-Plovdiv cells with the antibiotic G-418S in order to determine the concentrations at which G-418 causes cell death. A concentration of $0.4 \mathrm{mg} / \mathrm{ml}$ did not significantly alter the cells after $48 \mathrm{~h}$ of treatment (Figure 1). Higher G-418S concentrations $(0.6$ and $0.8 \mathrm{mg} / \mathrm{ml})$ perturbed both cell morphology and the state of the cell monolayer. Single living cells were observed at $0.6 \mathrm{mg} / \mathrm{ml}$ when treatment was prolonged to $96 \mathrm{~h}$ and no living cells were detected at a concentration of $0.8 \mathrm{mg} / \mathrm{ml}$ (Figure 1).
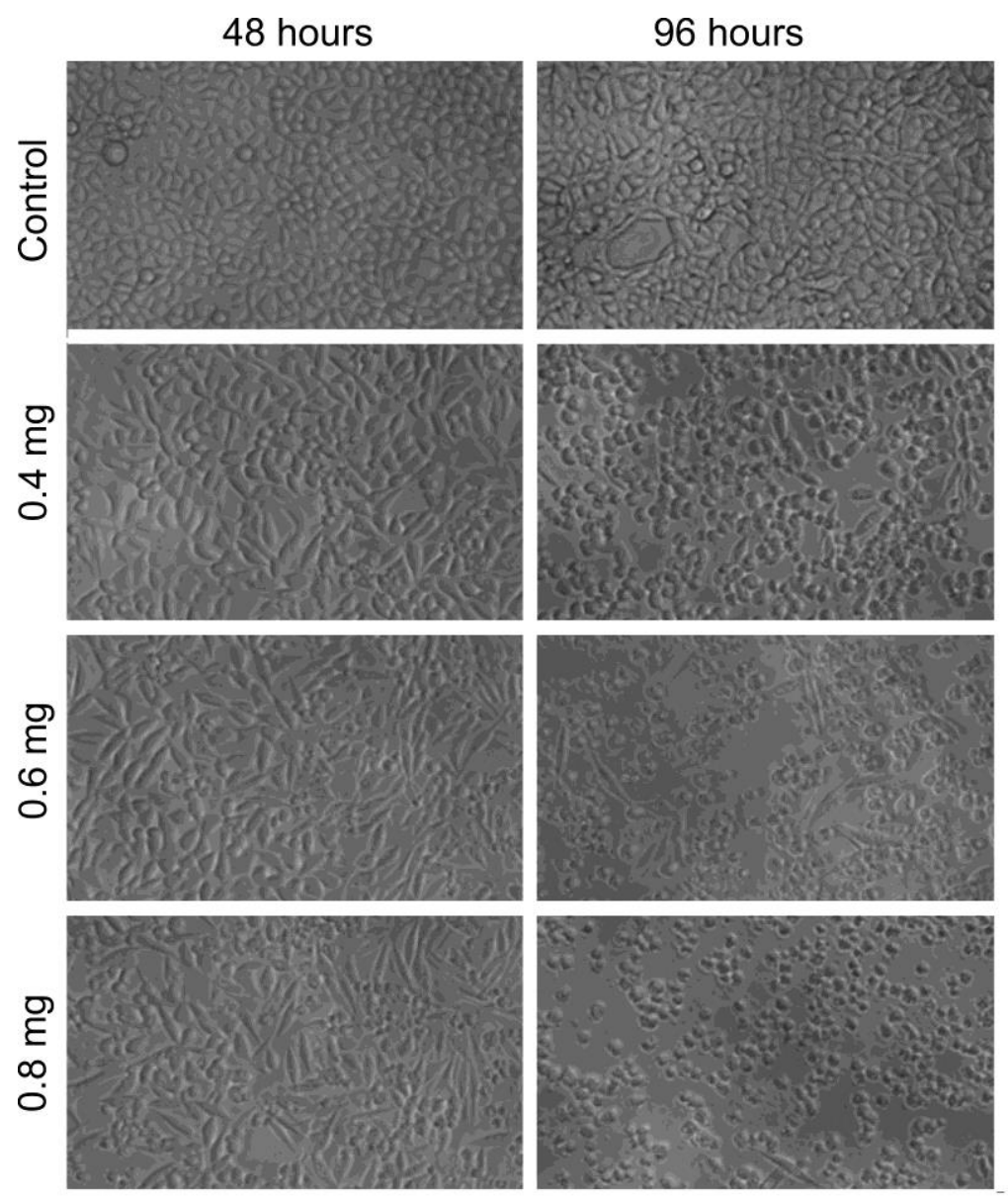

Figure 1. Microphotographs of McCoy-Plovdiv cells treated with antibiotic G-418 S for 48 hours (panel A) and 96 hours (panel B). Magnification: 200x.

Treatment with $0.4 \mathrm{mg} / \mathrm{ml} \mathrm{G}-418 \mathrm{~S}$ for $96 \mathrm{~h}$ did not significantly reduce cell vitality. However, most of the cells were rounded and the state of the monolayer differed compared to the control cells. The visual assessment of the cells was confirmed by the spectrophotometric results for cell vitality (Figure 2). For the highest concentrations of the antibiotic $(1.8 \mathrm{mg} / \mathrm{ml}$ and 
$2 \mathrm{mg} / \mathrm{ml}$ ) no living cells were detected even after $48 \mathrm{~h}$ of treatment. At $72 \mathrm{~h}$ single living cells were observed at a concentration of 1 $\mathrm{mg} / \mathrm{ml}$ and no living cells for the higher concentrations. After 96 h no living cells were present in the cell cultures treated with the antibiotic at concentrations $\geq 0.8 \mathrm{mg} / \mathrm{ml}$. The number of surviving cells in the cultures treated with $0.6 \mathrm{mg} / \mathrm{ml} \mathrm{G}-418 \mathrm{~S}$ was reduced to about $15 \%$ relative to the control. The relationship concentration-time-effect was also
ALEXANDROV V., et al. determined for the antibiotic G-418D. In this case, however, higher levels of cell vitality were detected for all studied concentrations (Figure 3). After $48 \mathrm{~h}$ of treatment significantly higher values for cell vitality were measured in cultures treated with $1-1.4 \mathrm{mg} / \mathrm{ml}$ of G-418D, compared to cultures treated with the same concentrations of G-418S. At $96 \mathrm{~h}$ a lot of living cells were detected even in the cultures treated with $0.8 \mathrm{mg} / \mathrm{ml}$ and $1 \mathrm{mg} / \mathrm{ml}$ G-418D (Figure 3).

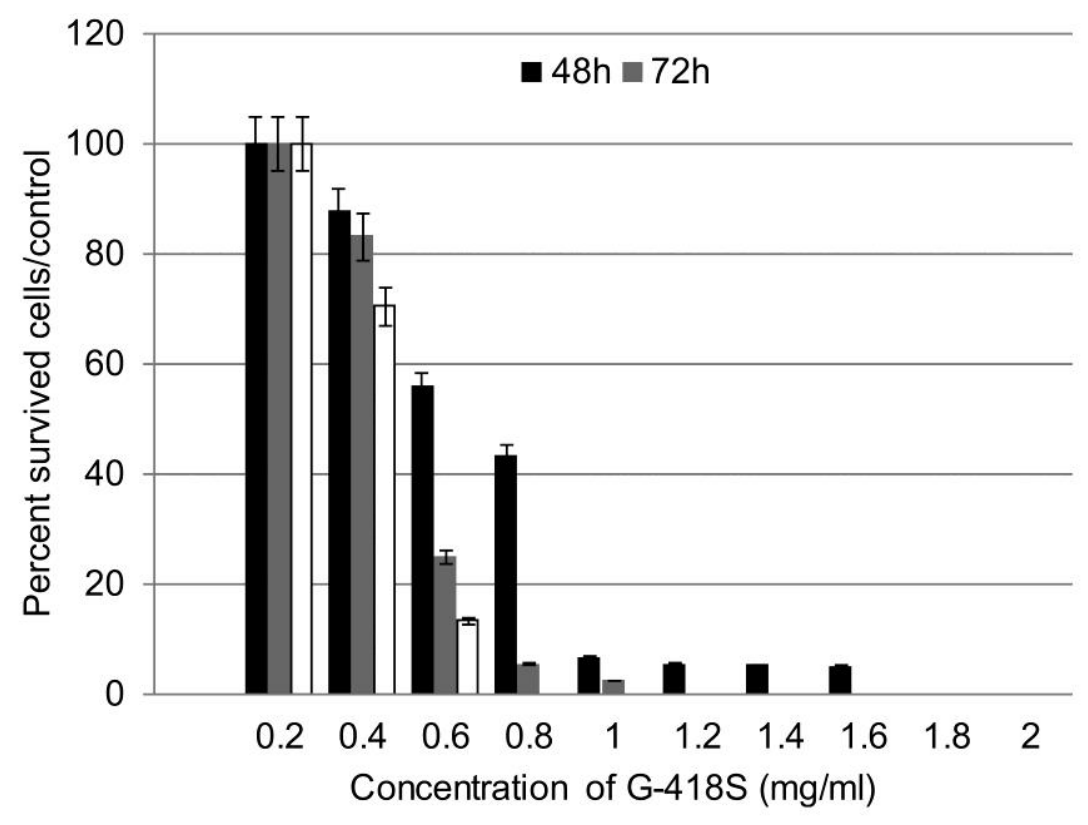

Figure 2. Cell vitality of McCoy-Plovdiv cells treated with different concentrations of the antibiotic G-418 S. Cell vitality was measured with WST-1 reagent at $48 \mathrm{~h}, 72 \mathrm{~h}$ and $96 \mathrm{~h}$ after onset of treatment. Results are represented as mean values from two independent experiments with three replicates in each.

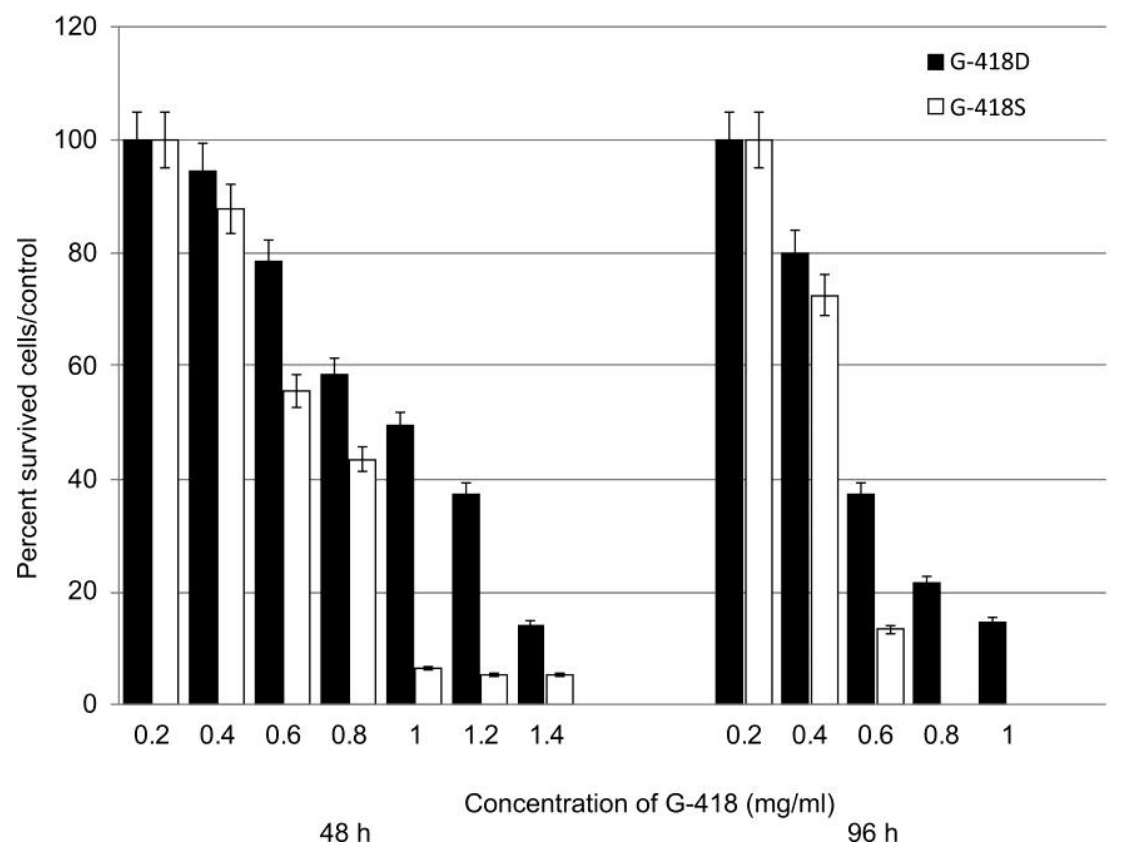

Figure 3. Cell vitality of McCoy-Plovdiv cells treated with different concentrations of the antibitoics G-418 B (black bars) and G-418 S (grey bars). Cell vitality was measured with WST-1 reagent $48 \mathrm{~h}$ and $96 \mathrm{~h}$ after onset of treatment. Results are represented as mean values from two independent experiments with three replicates in each. 


\section{Effect of medium replacement on selection with G-418S}

McCoy-Plovdiv cells were treated with G$418 \mathrm{~S}$ for $96 \mathrm{~h}$ with and without medium replacement and cell vitality was measured with the WST-1 reagent (Figure 4). Medium replacement was performed at 48 hours of treatment. At this time point the medium was exchanged with fresh medium containing antibiotic. Medium replacement did not notably affect cell cultures treated with 0.2 $\mathrm{mg} / \mathrm{ml}$ and $0.4 \mathrm{mg} / \mathrm{ml}$ of the antibiotic, whereas for a concentration of $0.6 \mathrm{mg} / \mathrm{ml}$, it led to total cell death. In contrast, cell vitality was $13.4 \%$ in cell cultures treated with the same antibiotic concentration but without medium replacement.

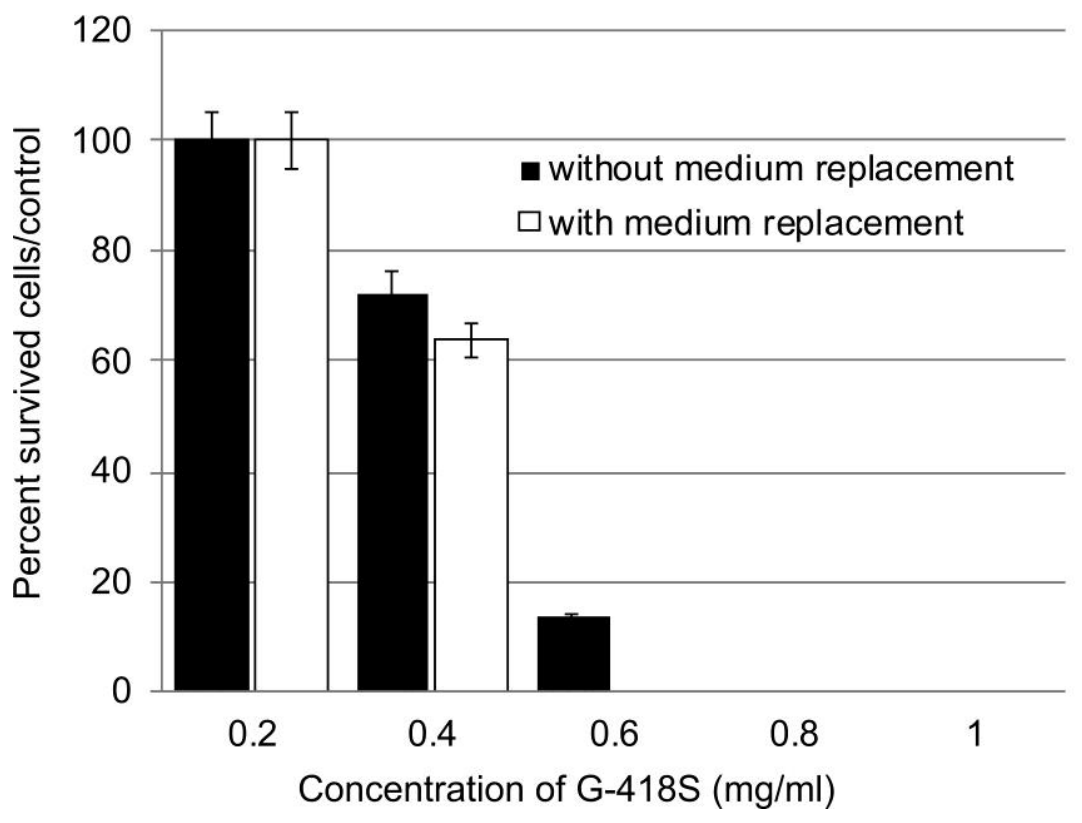

Figure 4. Cell vitality of McCoy-Plovdiv cells treated with different concentrations of the antibiotic G-418 S. Measurements were done at $96 \mathrm{~h}$ after onset of treatment without medium replacement (black bars) and with medium replacement (with fresh medium containing antibiotic) at $48 \mathrm{~h}$ (grey bars). Cell vitality was measured with WST-1 reagent $48 \mathrm{~h}$ and $96 \mathrm{~h}$ after onset of treatment. Results are represented as mean values from two independent experiments with three replicates in each.

\section{CONCLUSIONS}

Mammalian cells are commonly utilized for the production of recombinant proteins with therapeutic implications (13). Different cell cultures possess different transfection competence. The McCoy-Plovdiv cell culture has been developed as an in vitro cell system (10), in which cells are permanently cultured and maintained in serum-free and protein-free medium. In a pilot study (unpublished data) we have characterized the transfection potential of this cell line. For the isolation of positively transfected cells, several different selection systems can be exploited. One such system is based on the bacterial gene neo, which confers resistance to the antibiotic G418 (11). Mammalian cells have different sensitivity for G-418 (12) and this prompted us to determine the concentrations of the antibiotic, which efficiently kill untransfected cells. In respect to untransfected McCoyPlovdiv cells the effective antibiotic concentrations for selection are $0.4-0.6 \mathrm{mg} / \mathrm{ml}$ for G-418S and $0.8-1 \mathrm{mg} / \mathrm{ml}$ for G-418D. These concentrations should successfully eliminate untransfected cells if treatment of the cultures is performed 24-48 $\mathrm{h}$ after the transfection procedure. According to the data available in the literature, the stability of the antibiotic is maintained at $37^{\circ} \mathrm{C}$ for 8 days. We found that exchanging the medium in the cell culture by fresh one containing antibiotic increases cell death compared to cultures treated with no medium replacement. Despite the preserved stability of the antibiotic within this time period, some part of it is probably in a bound form, which leads to an overall reduction of the antibiotic concentration in the culture. This allows the survival and establishment of cell clones showing resistance at these concentrations of the antibiotic. Thus, medium replacement allows us to permanently maintain effective selective concentrations of the antibiotic.

We have already shown that foreign genetic material can be successfully introduced in serum-free McCoy-Plovdiv cells by transfection (unpublished data). In the current study we determined the cytotoxic effect of G418 on untransfected McCoy-Plovdiv cells and defined the range of concentrations at which 
this antibiotic can be applied as a selective agent in transfection procedures of this cell line. Future studies in this direction are needed in order to develop a system for stable transfection of McCoy-Plovdiv cells.

\section{ACKNOWLEGMENTS}

This research has been funded through the project DP 04/2013 from the Scientific and Mobile Projects at the Medical University Plovdiv

\section{REFERENCES}

1. Draganov, M., Murdgjeva, M., and Kamberov, M., Development of a new cell culture system, McCoy-Plovdiv. In Vitro Cell Dev. Biol. Anim., 36:284-286, 2000.

2. Draganov, M., Murdjeva, M., and Michailova-Topalska, T., McCoy and McCoy-Plovdiv cell lines in experimental and diagnostic practice - past, present and perspectives. J Culture Collections. 4:316, 2005.

3. Docheva, D., Draganov, M., and Murdgjeva, M., In vitro study on cytotoxic effect of some chemicals on serum McCoy and serum-free McCoyPlovdiv cell culture systems. Folia Medica. 40:43-45, 1999.

4. Draganova-Filipova, M., Murdjeva, M., Popova, Z., Peycheva, E., Miloshev, G., and Sarafian, V., Propolis induced apoptosis in McCoy Plovdiv cells. Biotechnol. Biotechnol. Equip, 23:635638, 2009.

5. Sarafian, V., Uzunova, Y., Hayrabedyan, S., Ganchevska, P., Filipova, M., Filipov, I., Lukanov, L., and Vladimirov, S.. Histo-blood group antigen expression and proliferative activity of fibroblasts treated with dental monomers. Cell Biol. Toxicol., 24:27-37, 2008.

6. Murdjeva, M., Draganov, M., Detection of Chlamydia trachomatis from urogenital specimens in a serum-free cell culture system. Biotechnol. Biotechnol. Equip., 16:173-176, 2002

7. Zagorov, M., Draganov, M., Alimanska, S., Staykova, N., Stefanov, R., Trayancheva, M., Kuzmanova, S., and Murdjeva, M., Indirect immunofluorescent assay for antinuclear antibodies on McCoy-Plovdiv serum-free cell line substrate. Comp. Immunol. Microbiol. Infect. Dis., 3:153-162, 2007

8. Murdjeva, M., Milieva, E., Stefanov, R., Draganov, M., and Krastev, P., Micrometric procedures in assessing antinuclear antibody patterns. Folia Medica, 3:182-186, 2014.

9. Fransazov, S., Draganov, M., Georgieva, B., Krastev, N., Popov, N., Gardjeva, P., and Murdjeva, M., Comparative study on different substrates of indirected immunofluorescent assay for antimitochondrial antibodies. Comptes rendus de l'Academie bulgare des Sciences. Medicine, 2:269-274, 2008.

10. Draganov, M., Murdjeva, M., and Sarafjan, V., Guidelines for cultivation and preservation of the serum-free cell line McCoy-Plovdiv. Cytotechnology, 42:163-167, 2003.

11. Southern, P., Berg, P.. Transformation of mammalian cells to antibiotic resistance with a bacterial gene under control of the SV40 early region promoter, J. Mol. Biol., 1:327-341, 1982.

12. Davis, G., Dibner, M., Battey J., Basic Methods in molecular biology. Elsevier New York, Amsterdam, London, UK, 1896.

13. Girard, P., Porte, L., Berta, T., Jordan, M., and Wurm, M., Calcium phosphate transfection optimization for serum-free suspension culture. Cytotechnology, 35:175-180, 2001. 